\title{
Perhitungan Beban Pencemaran Air Sungai Cibabat Kota Cimahi Provinsi Jawa Barat
}

\author{
Mochammad Azhar Rais Alfaroby ${ }^{{ }^{*}, \text { Eka Wardhani }^{2}}$ \\ ${ }^{1,2}$ Jurusan Teknik Lingkungan, Institut Teknologi Nasional (Itenas), Bandung \\ *Koresponden email: raisalfaroby08@gmail.com, ekawardhani08@gmail.com
}

Diterima : 28 Desember 2020

Disetujui: 3 Maret 2021

\begin{abstract}
The lack of domestic wastewater management services in the Cibabat River Basin has resulted in the Cibabat River being a place to collect domestic wastewater. This of course can reduce water quality as well as reduce the function of the river itself. The Cibabat river is known to be a sub-watershed of the Citarum River with a surface area of $1,855 \mathrm{~km}^{2}$. Activities in the Cibabat watershed contribute to the pollution load that causes the water quality of the Cibabat River to decline, which of course has an impact on the decrease in the quality of the river and increase in the polluting load that the river will receive. The research method uses the calculation of the pollutant load based on Permen LH 115/2003. The data used are secondary data from DLH Cimahi City, which conducted a water quality analysis at three points during three different seasons in 2019. One of the steps to overcome and control the pollution that occurs is to determine the actual pollutant load so that it can easily determine the application of effective technology for controlling river water pollution in the Cibabat River at theCimahi City.

Keywords: Cibabat, Cimahi, pollution load, water quality, pollution control

Abstrak

Kurangnya pelayanan pengelolaan air limbah domestik di daerah Aliran Sungai Cibabat membuat Sungai Cibabat dijadikan sebagai tempat penampung air limbah domestik. Aktivitas ini dapat menurunkan kualitas air dan juga menurunkan fungsi sungai itu sendiri. Diketahui sungai Cibabat termasuk sub DAS Sungai Citarum dengan luas DAS Cibabat mencapai $1,855 \mathrm{Km}^{2}$. Aktivitas di DAS Cibabat penyumbang beban pencemaran yang menyebabkan kualitas air Sungai Cibabat mengalami penurunan yang tentunya berdampak terhadap menurunnya mutu sungai dan meningkatkan beban pencemar yang akan diterima terima sungai. Metode penelitian menggunakan perhitungan beban pencemaran berdasarkan Permen LH 115/2003. Data yang dipergunakan yaitu data sekunder yang berasal dari DLH Kota Cimahi yang telah melakukan analisis kualitas air di tiga titik pada tiga musim yang berbeda di tahun 2019 Berdasarkan hasil analisa mutu air di Sungai Cibabat dikategorikan cemar sedang sampai berat yang meliputi ketiga periode musim pengukuran. Salah satu langkah untuk menanggulangi dan mengendalikan pencemaran yang terjadi yaitu dengan menentukan beban pencemar aktual sehingga mudah menentukan penerapan teknologi yang efektif dalam mengendalikan pencemaran air sungai yang terjadi di Sungai Cibabat, Kota Bandung.
\end{abstract}

Kata Kunci: Cibabat, Cimahi, beban pencemaran, mutu air, pengendalian pencemaran

\section{Pendahuluan}

Sungai Cibabat merupakan sub daerah aliran Sungai (DAS) Citarum yang berada di Kota Cimahi. Sungai ini berhulu di Kawasan Lembang, Kabupaten Bandung Barat dan mengalir ke arah selatan Kabupaten Bandung dan bermuara ke Sungai Citarum. Sungai Cibabat memiliki Panjang 35,05 Km dengan luas DAS $1,855 \mathrm{~km}^{2}$ [1]. Berkembangnya pembangunan, indusri dan meningkatnya laju pertumbuhan penduduk di DAS telah mempengaruhi kualitas air Sungai Cibabat. Parameter COD (Chemical oxygen demand) sebesar 68,89\% berasal dari kegiatan industri dan BOD (Biological oxygen demand) sebesar 39,98\% dari dari kegiatan domestik. Terdapat sebanyak 36 industri dengan komposisi 11 industri terletak di bagian tengah DAS dan 25 industri terletak di bagian hilir [1].

Sungai Cibabat sudah menjadi masalah yang perlu mendapatkan perhatian serius, karena sebagai sub DAS Citarum maka pencemaran yang terjadi di sungai ini akan memperburuk kondisi Sungai Citarum. Kualitas air Sungai Citarum telah tercemar polutan yang berasal dari anak-anak sungainya. Penelitian daya tampung di Sungai Citarik sebagai salah satu anak Sungai Citarum menyebutkan bahwa 
parameter BOD dan COD telah melebihi daya tampung sungai sehingga memberi beban kepada Sungai Citarum [2]. Salah satu sumber pencemar yang menyumbang beban pencemar yaitu sektor industri diantaranya tekstil [3]. Sungai Citarum telah tercemar berat bahkan beberapa logam berat diantaranya Cd dan $\mathrm{Pb}$ telah terindentifikasi di airnya. Hal tersebut menyebabkan penurunan fungsi dari sungai ini.

Sungai Citarum merupakan sumber utama untuk tiga waduk utama di Provinsi Jawa Barat. Waduk Saguling merupakan waduk pertama yang membendung sungai ini. Pencemaran yang terjadi di Sungai Citarum dan anak-anak sungainya akan mempengaruhi operasional Waduk Saguling [4] [5]. Dampak pencemaran yang terjadi di Sungai Citarum dan anak sungainya telah mencemari Waduk Saguling. Hal tersebut terlihat dari kualitas air waduk ini yang telah tercemar [6] [7]. Beratnya pencemaran yang terjadi di Sungai Citarum menyebabkan terjadi akumulasi pencemar diantaranya beberapa logam berat di sedimen Waduk Saguling. Hal tersebut memerlukan penanganan segera mengingat Waduk Saguling berfungsi sebagai sumber air baku, irigasi dan budidaya areal perikanan jaring terapung [8] [9] [10].

Berdasarkan permasalahan tersebut, pentingnya melakukan kajian dan analisis kualitas air Sungai Cibabat dengan penentuan status mutu air serta perhitungan beban pencemaran sungai sebagai data dasar dalam penentuan teknologi pengendalian pencemaran air yang tepat. Penelitian mengenai kualitas air telah dilakukan di banyak tempat seperti analisis kualitas air dan daya tampung sungai dengan Metode Qual2Kw (studi kasus: Sungai Code, Yogyakarta) [11]. Analisis kualitas air dan status mutu serta beban pencemaran Sungai Mahap di Kabupaten Sekadau Kalimantan Barat [12]. Pengendalian air lindi pada proses penutupan TPA Gampong Jawa terhadap kualitas air sumur [13]. Mengingat besarnya sumbangan beban pencemaran dari Sungai Cibabat ke Sungai Citarum sehingga penelitian ini dapat membantu program Citarum Harum yang telah dicanangkan pemerintah dalam rangka perbaikan kualitas Sungai Citarum beserta anak sungainya dan Waduk Saguling.

\section{Metode Penelitian}

Data yang digunakan dalam penelitian ini merupakan data sekunder dari Pemerintah Kota Cimahi seperti data kualitas air dan profil Sungai Cibabat tahun 2019, dokumen RTRW, buku putih sanitasi, data penduduk/sebaran aktivitas di sekitar Sungai Cibabat dan data lainnya. Titik pemeriksaan kualitas air Sungai Cibabat dilakukan di tiga lokasi yaitu segmen hulu pada koordinat 06 52 '28,9'"LS; $107^{\circ} 33^{\prime} 41,3$ 'BT, segmen tengah pada koordinat $06^{\circ} 53$ '21,9'LS; $107^{\circ} 33^{\prime} 24,3$ ”BT, dan segmen hilir pada koordinat $06^{\mathrm{O}} 54^{\prime} 00,8^{\prime \prime} \mathrm{LS} ; 107^{\mathrm{O}} 32$ '54,6”BT [1].

Cara menganalisis kualitas air Sungai Cibabat dilakukan dengan perbandingan data yang diperoleh terhadap baku mutu setiap parameter Peraturan pemerintah No 82 tahun 2001 (PP 82/2001) tentang Pengelolaan Kualitas Air dan Pengendalian pencemaran Air peruntukan air kelas dua. Parameter yang tidak memenuhi baku mutu dianalisis sebab akibat melalui analisis deskripsi, setelah itu dilakukan penentuan status mutu air Sungai Cibabat melalui perhitungan metode indeks pencemar (IP) berdasarkan Keputusan Menteri Lingkungan Hidup No 115 tahun 2003 [14] tentang penentuan status kualitas air, sehingga nilai klasifikasi indeks pencemar Sungai Cibabat diketahui.

Perhitungan beban pencemar dibagi menjadi dua yaitu beban pencemar maksimum (BPM) yang merupakan beban pencemaran yang diperbolehkan di suatu badan air berdasarkan peruntukannya. Penentuan BPM dilakukan dengan mengalikan antara debit sungai yang ditinjau dengan konsentrasi parameter tertentu berdasarkan baku mutu. Beban pencemar yang kedua yaitu beban pencemar actual (BPA) yang merupakan beban pencemaran yang dihasilkan di suatu sungai pada saat kondisi eksisting. BPA diperoleh dengan mengalikan antara debit dengan konsentrasi parameter yang terukur. Selisih antara BPM dan BPA dijadikan suatu penentu apakan suatu sungai beban pencemarannya telah terlampaui atau belum, jika telah terlampaui makan harus segera dilakukan pengendalian pencemaran air [14].

\section{Hasil dan Pembahasan}

Aliran air Sungai Cibabat melewati dua kecamatan, yaitu Cimahi Tengah dan Cimahi Selatan luas kelurahan yang termasuk ke dalam DAS Cibabat dapat dilihat pada Tabel 1. Kelurahan terbesar yang masuk ke DAS Cibabat yaitu Cigugur tengah, Kecamatan Cimahi Tengah. Jumlah Industri yang berada di daerah Sungai Cibabat sebanyak 36 industri, terdiri dari industri tekstil, farmasi, rumah sakit, industri cat dan lain-lain. Peta DAS Sungai Cibabat dapat dilihat pada Gambar 1. 
Tabel 1. Luas wilayah DAS Cibabat $\left(\mathrm{Km}^{2}\right)$

\begin{tabular}{ccccc}
\hline \multirow{2}{*}{ No } & \multirow{2}{*}{ Kecamatan } & \multirow{2}{*}{ Kelurahan } & $\begin{array}{c}\text { Luas Dalam } \\
\text { DAS }\end{array}$ & \multirow{2}{*}{ Luas Total Kelurahan } \\
\hline 1. & Cimahi Tengah & Cigugur Tengah & 1,116 & 2,531 \\
2. & Cimahi Tengah & Baros & 0,085 & 2,25 \\
3. & Cimahi Selatan & Utama & 0,654 & 3,081 \\
\hline & & & 1,855 & 7,862 \\
\hline
\end{tabular}

Sumber: Pengolahan data [1]

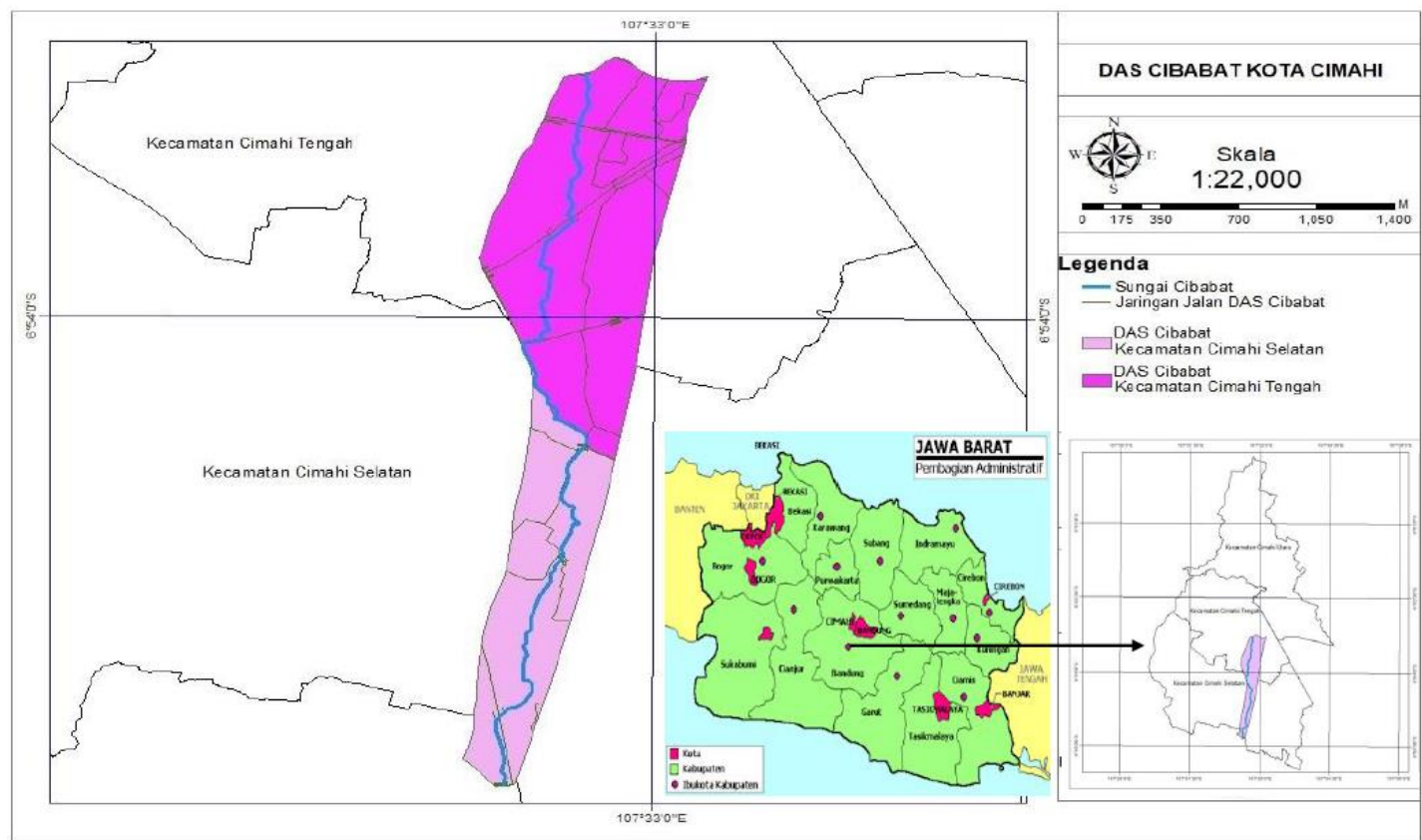

Gambar 1. Peta DAS Cibabat Sumber: [1]

Sektor pertanian di DAS Cibabat terdiri dari sawah dan kebun. Luas lahan sektor pertanian di dalam DAS Cibabat 18,31 Ha seperti disajikan pada Tabel 2. Data sektor ini diperlukan untuk menganalisis pengaruh besarnya polutan yang masuk ke badan air Sungai Cibabat yang dihasilkan dari kegiatan pertanian dan perkebunan. Sektor pertanian cukup berperan penting sebagai penumbang polutan organik terhadap badan air disekitarnya, dikarenakan penggunaan pestisida dan urea yang menjadi zat pencemar organik dalam badan air.

Tabel 2. Luas lahan sektor pertanian di DAS Cibabat

\begin{tabular}{cccc}
\hline No & Nama Keamatan & $\begin{array}{c}\text { Sawah Di DAS } \\
\text { Cibabat (Ha) }\end{array}$ & $\begin{array}{c}\text { Kebun Di DAS } \\
\text { Cibabat (Ha) }\end{array}$ \\
\hline 1 & Cimahi Tengah & 1,12 & 18,31 \\
2 & Cimahi Selatan & 11,4 & - \\
\hline & Total & 12,52 & 18,31 \\
\hline
\end{tabular}

Sumber: Pengolahan data [1]

Sungai Cibabat memiliki lebar berkisar antara 1,5 - 6,7 meter dengan kedalaman berkisar antara 0,1-1,3 meter termasuk kategori sungai kecil. Debit sungai berkisar antara 0,24-1,44 $\mathrm{m}^{3} / \mathrm{detik}^{\mathrm{seperti}}$ disajikan pada Gambar 2. Sementara Tabel 3 menyajikan rekapitulasi kualitas Sungai Cibabat dalam 3 musim pemantauan yaitu musim pancaroba, kemarau, dan hujan pada Tahun 2019 yang tidak memenuhi baku mutu berdasarkan PP 82/2001 [1]. 


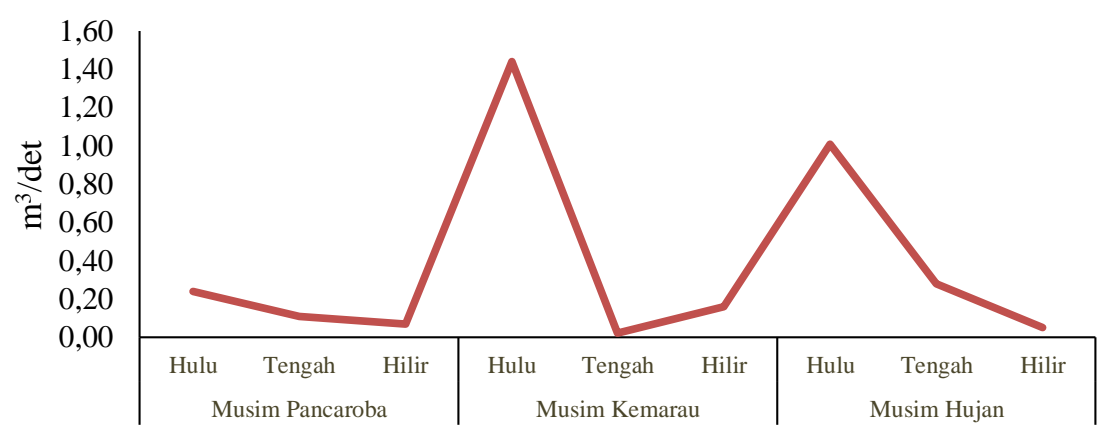

Titik lokasi dan periode pengukuran

Gambar 2. Debit air Sungai Cibabat di ketiga musim tahun 2019

Sumber: Pengolahan data [1]

\section{Parameter Fisika}

Parameter fisika merupakan parameter yang dalam prosesnya dapat dilihat secara fisik. Parameter yang tidak memenuhi baku mutu di sungai Cibabat yaitu TDS dan TSS. Hasil pengukuran parameter TDS pada bagian hulu dan tengah sungai cibabat memenuhi baku mutu Kelas II berdasarkan PP 82/2001 yaitu sebesar $342 \mathrm{mg} / \mathrm{l}$ dan $450 \mathrm{mg} / \mathrm{l}$. Sedangkan pada bagian hilir sungai, parameter TDS melebihi baku mutu yaitu $1.784 \mathrm{mg} / \mathrm{l}$. Hasil pengukuran parameter TDS pada bagian hulu dan tengah Sungai Cibabat di musim kemarau dan hujan telah memenuhi baku mutu yaitu sebesar $398 \mathrm{mg} / \mathrm{l}$ dan $408 \mathrm{mg} / \mathrm{l}$ pada musim hujan dan $430 \mathrm{mg} / \mathrm{l}$ dan $530 \mathrm{mg} / \mathrm{l}$ pada musim hujan. Bagian hilir sungai di kedua musim tersebut, parameter TDS melebihi baku mutu yaitu $1.704 \mathrm{mg} / \mathrm{l}$ musim kemaran dan $3.076 \mathrm{mg} / \mathrm{l}$ dimusim hujan.

Hasil pengukuran TSS pada bagian hulu, tengah, dan hilir sungai memenuhi baku mutu berdasarkan PP No. 82/2001 yaitu sebesar 26 mg/ L, 23,5 mg/ dan L, 32 mg/ L. Hasil pengukuran musim kemarau pada bagian hulu sungai memenuhi baku mutu yaitu sebesar $48 \mathrm{mg} / \mathrm{l}$. Bagian tengah dan hilir sungai, parameter TSS melebihi baku mutu yaitu 346 dan $74 \mathrm{mg} / \mathrm{l}$. Hasil pengukuran musim hujan pada bagian hulu, tengah, dan hilir sungai memenuhi baku mutu yaitu sebesar $21 \mathrm{mg} / \mathrm{L}, 35 \mathrm{mg} / \mathrm{dan} \mathrm{L}, 36$ $\mathrm{mg} / \mathrm{l}$.

Tabel 3. Data kualitas air Sungai Sungai Cibabat di ketiga musim 2019

\begin{tabular}{|c|c|c|c|c|c|c|c|c|c|c|c|c|}
\hline \multirow{3}{*}{ No } & \multirow{3}{*}{ Parameter } & \multirow{3}{*}{ Satuan } & \multirow{3}{*}{$\begin{array}{c}\text { Baku } \\
\text { Mutu } \\
\text { (Kelas } \\
\text { II) }\end{array}$} & \multicolumn{9}{|c|}{ Musim } \\
\hline & & & & \multicolumn{4}{|c|}{ Pancaroba } & \multicolumn{3}{|c|}{ Kemarau } & \multicolumn{2}{|c|}{ Hujan } \\
\hline & & & & Hulu & Tengah & Hilir & Hulu & Tengah & Hilir & Hulu & Tengah & Hilir \\
\hline & Parameter Fisika & & & & & & & & & & & \\
\hline 1 & TDS & $\mathrm{mg} / \mathrm{L}$ & 1.000 & 342 & 450 & 1.784 & 398 & 408 & 1.704 & 430 & 530 & 3.076 \\
\hline \multirow[t]{2}{*}{2} & TSS & $\mathrm{mg} / \mathrm{L}$ & 50 & 26 & 23,5 & 32 & 48 & 346 & 74 & 21 & 35 & 36 \\
\hline & Kimia Anorganik & & & & & & & & & & & \\
\hline 3 & $\mathrm{BOD}_{5}$ & $\mathrm{mg} / \mathrm{L}$ & 3 & 6 & 24 & 46 & 15 & 83 & 78 & 47 & 59 & 61 \\
\hline 4 & COD & $\mathrm{mg} / \mathrm{L}$ & 25 & 29 & 60 & 122 & 77 & 112 & 138 & 126 & 151 & 200 \\
\hline 5 & DO & $\mathrm{mg} / \mathrm{L}$ & $>4$ & 5,38 & 2,10 & 2,27 & 3,71 & 1,16 & 1,22 & 3,97 & 1,03 & 1,3 \\
\hline 6 & Phosphat & $\mathrm{mg} / \mathrm{L}$ & 0,2 & 0,48 & 0,93 & 1,08 & $<0,16$ & 0,26 & 0,16 & $<0.16$ & 0,5 & 0,3 \\
\hline 7 & Tembaga (Cu) & $\mathrm{mg} / \mathrm{L}$ & 0,02 & 0,0131 & $<0,012$ & 0,0128 & $<0,012$ & $<0,012$ & $<0,012$ & $<0.012$ & $<0.012$ & 0,04 \\
\hline 8 & Timbal $(\mathrm{Pb})$ & $\mathrm{mg} / \mathrm{L}$ & 0,03 & $<0,03$ & $<0,03$ & 0,0751 & $<0,03$ & $<0,03$ & $<0,03$ & $<0.03$ & $<0.03$ & 0,08 \\
\hline 9 & Seng $(\mathrm{Zn})$ & $\mathrm{mg} / \mathrm{L}$ & 0,05 & 0,048 & 0,054 & 0,083 & 0,067 & 0,027 & 0,11 & 0,04 & 0,08 & 0,21 \\
\hline 10 & Sulfida & $\mathrm{mg} / \mathrm{L}$ & 0,002 & 0,097 & 0,043 & 0,10 & 0,35 & 0,96 & 0,45 & 0.10 & 0,11 & 0,09 \\
\hline 11 & Nitrit $\left(\mathrm{NO}_{2}-\mathrm{N}\right)$ & $\mathrm{mg} / \mathrm{L}$ & 0,06 & 0,305 & $<0,01$ & $<0,01$ & 0,192 & 0,010 & 0,01 & 0,29 & $<0.01$ & $<0.01$ \\
\hline 12 & Klorin Bebas & $\mathrm{mg} / \mathrm{L}$ & 0,03 & 0,04 & 0,06 & 0,09 & 0,08 & 0,17 & 0,05 & 0,02 & 0.03 & 0,04 \\
\hline \multirow[t]{2}{*}{13} & Amoniak $\left(\mathrm{NH}_{3}-\mathrm{N}\right)$ & $\mathrm{mg} / \mathrm{L}$ & 0,02 & 1,1 & 1,1 & 1,1 & 1,4 & 1,1 & 8,4 & 1,1 & 17.6 & 6,4 \\
\hline & Mikrobiologi & & & & & & & & & & & \\
\hline 14 & Total Coliform & $\mathrm{Jml} / 0,1 \mathrm{~L}$ & 5.000 & $1,1 \times 10^{5}$ & $1,1 \times 10^{5}$ & $1,1 \times 10^{5}$ & $1.17 \times 10^{5}$ & $21 \times 10^{5}$ & $77 \times 10^{6}$ & $27,5 \times 10^{6}$ & $92 \times 10^{6}$ & $36,5 \times 10^{6}$ \\
\hline \multirow[t]{2}{*}{15} & Fecal Coliform & $\mathrm{Jml} / 0,1 \mathrm{~L}$ & 1.000 & $1,1 \times 10^{5}$ & $1,1 \times 10^{5}$ & $1,1 \times 10^{5}$ & $5,2 \times 10^{4}$ & $7.8 \times 10^{5}$ & $15 \times 10^{6}$ & $5.4 \times 10^{5}$ & $12 \times 10^{6}$ & $21,8 \times 10^{5}$ \\
\hline & Kimia Organik & & & & & & & & & & & \\
\hline 16 & Fenol & $\mathrm{mg} / \mathrm{L}$ & 0,001 & 0,0313 & 0,0888 & 0,044 & 0,005 & 0,0287 & 0,0253 & 1,21 & 0,001 & 0,1787 \\
\hline 17 & Detergen sebagai MBAS & $\mathrm{mg} / \mathrm{L}$ & 0,2 & 0,044 & 0,101 & 0,547 & 1,48 & 2,73 & 2,8 & $<0.02$ & 0,2 & 0,2 \\
\hline
\end{tabular}

Keterangan: Angka warna merah = melebihi baku mutu PP 82/2001 Kelas II. 


\section{Parameter Kimia}

Parameter kimia merupakan parameter yang di dalamnya terjadi reaksi secara kimia, parameter kimia yang melebihi baku mutu yaitu $\mathrm{BOD}_{5}$. Hasil pengukuran $\mathrm{BOD}_{5}$ musim pancaroba pada bagian hulu hingga hilir sungai tidak memenuhi baku mutu Kelas II berdasarkan PP 82/2001 yaitu, sebesar 6 mg/L, 24 $\mathrm{mg} / \mathrm{L}$, dan $46 \mathrm{mg} / \mathrm{L}$. Parameter $\mathrm{BOD}_{5}$ pada bagian hulu hingga hilir mengalami peningkatan konsentrasi $\mathrm{BOD}_{5}$ yang sangat signifikan. Hal ini dikarenakan, pada bagian tengah terjadi penambahan beban pencemar yaitu material organik yang berasal terutama dari sektor permukiman. Tingginya konsentrasi $\mathrm{BOD}_{5}$ mengindikasikan bahwa perairan sudah tercemar [16]. Pengukuran $\mathrm{BOD}_{5}$ musim kemarau bagian hulu hingga hilir sungai tidak memenuhi baku mutu yaitu sebesar $29 \mathrm{mg} / \mathrm{L}, 22 \mathrm{mg} / \mathrm{L}$, dan $51 \mathrm{mg} / \mathrm{L}$. Hasil pengukuran pada bagian hulu hingga hilir sungai tidak memenuhi baku mutu yaitu sebesar $22 \mathrm{mg} / \mathrm{L}, 39$ $\mathrm{mg} / \mathrm{L}$, dan $21 \mathrm{mg} / \mathrm{L}$.

Baku mutu parameter COD dalam sebuah perairan yaitu sebesar $25 \mathrm{mg} / \mathrm{L}$ untuk kelas II. Bagian hulu, tengah, hingga hilir sungai kandungan COD tidak memenuhi baku mutu PP 82/2001. Besarnya kandungan COD dari hasil pengukuran yang dilakukan musim pancaroba yaitu sebesar $29 \mathrm{mg} / \mathrm{L}, 60$ $\mathrm{mg} / \mathrm{L}$, dan $122 \mathrm{mg} / \mathrm{L}$. Sementara baku mutu parameter DO dalam air sungai yaitu > $4 \mathrm{mg} / \mathrm{L}$. Kadar nilai DO Jenuh pada Temperatur $25^{\circ} \mathrm{C}$ dalam suatu perairan yaitu sebesar 8,26 . Berdasarkan hasil pengukuran yang dilakukan di 3 musim, parameter DO yang mendominasi tidak memenuhi baku mutu pada musim kemarau dan hujan dibagian tengah dan hilir sungai. Hasil pengukuran di dalam 3 musim pada bagian tengah dan hilir sungai tidak memenuhi baku mutu berdasarkan PP 82/2001 dengan nilai kadar DO sebagai contoh yaitu sebesar $2,10 \mathrm{mg} / \mathrm{L}$ dan $2,27 \mathrm{mg} / \mathrm{L}$ pada musim pancaroba.

Hasil pengukuran parameter Phospat pada sungai cibabat yaitu tidak memenuhi baku mutu pada musim pancaroba disemua titik dan di beberapa titik pengukuran di musim hujan dan juga musim kemarau. Hasil pengukuran parameter Phospat pada bagian hulu hingga hilir sungai dimusim pancaroba mengalami peningkatan konsentrasi Phospat, maka hasil pengukuran pada bagian hulu hingga hilir sungai dinyatakan tidak memenuhi baku mutu Kelas II berdasarkan PP 82/2001 dikarenakan nilai phosfat yang tinggi yaitu sebesar $0,48 \mathrm{mg} / \mathrm{L}, 0,93 \mathrm{mg} / \mathrm{L}$ dan $1,08 \mathrm{mg} / \mathrm{L}$. Tingginya kadar phosfat dalam badan air pada bagian hulu hingga hilir mengindikasikan besarnya pencemaran bahan organik yang diprediksi berasal dari sektor pertanian dan peternakan yang ada dibagian hulu Sungai Cibabat di tambah adanya kegiatan domestik dan industri sebagai bagian dari sumber pencemar pada bagian tengah dan hilir yang menjadi penyebab tingginya kadar phosfat. Pengukuran pada bagian tengah sungai dimusim kemarau dan hujan dihasilkan tidak memenuhi baku mutu dengan nilai phosfat yang dihasilkan yaitu sebesar $0,26 \mathrm{mg} / \mathrm{L}$ dan $0,5 \mathrm{mg} / \mathrm{L}$.

Berdasarkan PP 82/2001 baku mutu parameter $\mathrm{Cu}$ dalam air sungai yaitu sekitar <0,02 mg/ L. Berdasarkan hasil pengukuran parameter $\mathrm{Cu}$ pada Sungai Cibabat, terdapat beberapa bagian sungai yg tidak memenuhi baku mutu pada bagian hilir sungai di musim hujan dinyatakan tidak memenuhi baku mutu berdasarkan PP 82/2001. Keberadaan $\mathrm{Cu}$ di suatu perairan umum dapat berasal dari daerah industri yang berada di sekitar perairan tersebut. Keberadaan Logam ini akan terserap oleh biota perairan secara berkelanjutan apabila keberadaannya dalam perairan selalu tersedia. Terlebih lagi bagi biota perairan dengan mobilitas yang rendah seperti kerang. Mengingat akan bahaya yang ditimbulkan, maka perlu dilakukan tindakan dalam pengendalian pencemaran khususnya dari sektor industri nakal yang membuang limbahnya disaat musim hujan [16].

Baku mutu parameter $\mathrm{Pb}$ dalam air sungai yaitu harus $0,03 \mathrm{mg} / \mathrm{L}$ untuk kelas II. berdasarkan $\mathrm{PP}$ 82/2001. Berdasarkan hasil pengukuran parameter $\mathrm{Pb}$ pada Sungai Cibabat tidak memenuhi baku mutu pada musim pancaroba dan hujan dibeberapa titik pengukuran. parameter $\mathrm{Pb}$ pada bagian hilir sungai dalam kedua musim dinyatakan tidak memenuhi baku mutu. Keberadaan $\mathrm{Pb}$ dalam badan air Sungai Cibabat mengindikasikan adanya pencemaran limbah yang berasal dari sektor industri yg menjadi salah satu sumber pencemaran logam berat yang berada dibagian hilir sungai. Tingginya kandungan timbal dalam badan air akan menyebabkan biota air tercemar seperti ikan, udang dan kerang, dimana biota tersebut hidup di dasar sungai dan apabila dikonsumsi dapat berbahaya bagi kesehatan dan hal ini perlu ditindak lanjuti [16].

Sulfida merupakan gas yang sangat beracun dan berbau busuk oleh adanya aktifitas pembusukan oleh bakteri pengurai, sehingga kehadirannya dalam badan air akan mempengaruhi terhadap kualitas air sungai [16]. Berdasarkan PP 82/2001 untuk kelas II baku mutu parameter sulfida dalam air yaitu 0,002 mg/ L. Hasil pengukuran parameter Sulfida yang didapatkan pada Sungai Cibabat tidak memenuhi baku mutu yang terjadi disemua musim pengukuran. Parameter Sulfida pada seluruh musim dan bagian titik pengukuran sungai dinyatakan sudah tidak memenuhi baku mutu. Kadar nilai tertinggi sulfida terjadi 
pada bagian hulu, tengah, dan hilir pengukuran disaat musim kemarau. Tingginya kandungan sulfida disebabkan oleh adanya oksidasi biologi yang terjadi oleh mikroorganisme dalam badan air yang disebabkan oleh besarnya kandungan pencemar organik yang ada dan merupakan salah satu hal yang mempengaruhi tingginya nilai BOD dan berkurangnya nilai DO pada sutu badan air [16].

Kandungan Nitrit pada perairan alami sekitar 0,001 mg/L [16]. Berdasarkan PP 82/2001 untuk kelas II baku mutu parameter nitrit dalam air yaitu harus $0,06 \mathrm{mg} / \mathrm{L}$. Kadar Nitrit yang lebih dari 0.06 $\mathrm{mg} / \mathrm{L}$ akan bersifat toksik bagi organisme perairan. hasil pengukuran parameter nitrit pada bagian hulu di seluruh musim dinyatakan tidak memenuhi baku mutu air. Tingginya kadar Nitrit pada bagian hulu sungai menggambarkan berlangsungnya proses biologis perombakan bahan organik yang memiliki kadar oksigen terlarut yang rendah. kadar Nitrit yang lebih dari $0.06 \mathrm{mg} / \mathrm{L}$ adalah bersifat toksik bagi organisme perairan [16].

Klorin bebas adalah jumlah klorin yang dapat menonaktifkan mikroorganisme patogen yang ada dalam air. Ini adalah konsentrasi klorin dalam bentuk gas klor terlarut. pengukuran klorin bebas dalam air [16]. Berdasarkan PP 82/2001 untuk air kelas II baku mutu parameter keberadaan klorin bebas dalam air yaitu sekitar $0,03 \mathrm{mg} / \mathrm{L}$. Berdasarkan hasil pengukuran, parameter klorin bebas tidak memenuhi baku mutu di beberapa titik pada musim pancaroba,dan kemarau. Hasil pengukuran parameter klorin bebas di musim pancaroba, dan musim kemarau dinyatakan tidak memenuhi baku mutu terutama pada saat musim kemarau, tingginya kadar klorin bebas terjadi di bagian tengah Sungai Cibabat.

Baku mutu yang digunakan parameter Amonia yaitu $<0,02 \mathrm{mg} / \mathrm{L}$ untuk kelas II. Berdasarkan hasil pengukuran, parameter Amonia tidak memenuhi baku mutu disemua titik pada musim pancaroba, kemarau dan hujan. Kadar ammonia yang tinggi dapat merupakan indikasi adanya pencemaran bahan organik yang berasal dari limbah domestik, industri, dan limpasan pupuk pertanian [16]. Kandungan amonia ada dalam jumlah yang relatif kecil jika di dalam perairan kandungann oksigen terlalu tinggi. Berdasarkan hasil pengukuran parameter ammoniak tidak memenuhi baku mutu di ketiga musim dan juga disemua titik bagian sungai. Diperkirakan tingginya kadar ammoniak pada Sungai Cibabat bersumber dari proses reduksi gas nitrogen yang berasal dari proses difusi udara atmosfer, limbah industri, dan domestik. Amonia yang terdapat dalam mineral masuk kebadan air melalui erosi tanah dan terbawa oleh aliran Sungai Cibabat.

Berdasarkan PP No.82 Tahun 2001 baku mutu kadar fenol yang di perbolehkan untuk kelas II yaitu sebesar 0,001 mg/l. Berdasarkan hasil pengukuran, parameter fenol tidak memenuhi baku mutu pada semua titik lokasi sampling dan ketiga musim pengukuran. Baku mutu yang digunakan parameter detergen sebagai MBAS yaitu 0,2 mg/L untuk kelas II. Berdasarkan hasil pengukuran, parameter detergen sebagai MBAS tidak memenuhi baku mutu dibeberapa titik sampling dan musim. Hasil pengukuran untuk parameter detergen tidak memenuhi baku mutu air di di bagian hilir musim pancaroba, dan tidak memenuhi baku mutu air di seluruh bagian lokasi sampling pada musim kemarau. Tingginya kadar detergen pada Sungai Cibabat disaat musim kemarau bersumber dari berbagai sektor seperti industri ataupun domestik, ditambah rendahnya kuantitas air sungai di musim kemarau menyebabkan tingginya konsentrasi detergen dalam badan sungai.

\section{Parameter Mikrobiologi}

Parameter mikrobiologi adalah parameter yang dalam prosesnya melibatkan mikroorganisme. Parameter mikrobiologi terdiri dari total coliform dan fecal coliform. Berdasarkan PP 82/2001 untuk air kelas II baku mutu yang digunakan parameter total coliform yaitu 5.000 jumlah/100 ml sampel. Berdasarkan hasil pengukuran sampel air sungai, parameter total coliform tidak memenuhi baku mutu disemua titik sampling baik musim pancaroba, kemarau maupun hujan. Hasil pengukuran pada bagian hulu hingga hilir sungai musim pancaroba tidak memenuhi baku dengan jumlah total coliform yaitu 1.100 .000 jumlah/100 ml, pada setiap titik bagian sampling sungai. Diketahui kadar total coliform tertinggi terdapat pada bagian tengah sungai yang terjadi di musim hujan dengan jumlah total coliform sebesar 92.080.000 jumlah/100 ml sampel. Baku mutu yang digunakan sesuai PP 82/2001 untuk parameter fecal coliform yaitu 1.000 jumlah/100 ml. Berdasarkan hasil pengukuran, jumlah fecal coliform tidak memenuhi baku mutu di semua titik sampling pada ketiga musim. Kadar fecal coliform yaitu sebesar 1.100.000 jumlah/100 ml pada setiap titik bagian sampling sungai. Diketahui kadar total coliform tertinggi terdapat pada bagian hilir sungai yang dilakukan pada pengukuran musim hujan dengan jumlah fecal coliform sebesar 27.870.000 jumlah/100 ml sampel.

Berdasarkan hasil perhitungan mengacu pada Kepmen LH 115/2003 status mutu air di Sungai Cibabat termasuk kategori cemar ringan sampai berat seperti disajikan pada Gambar 3 dan Tabel 4. 


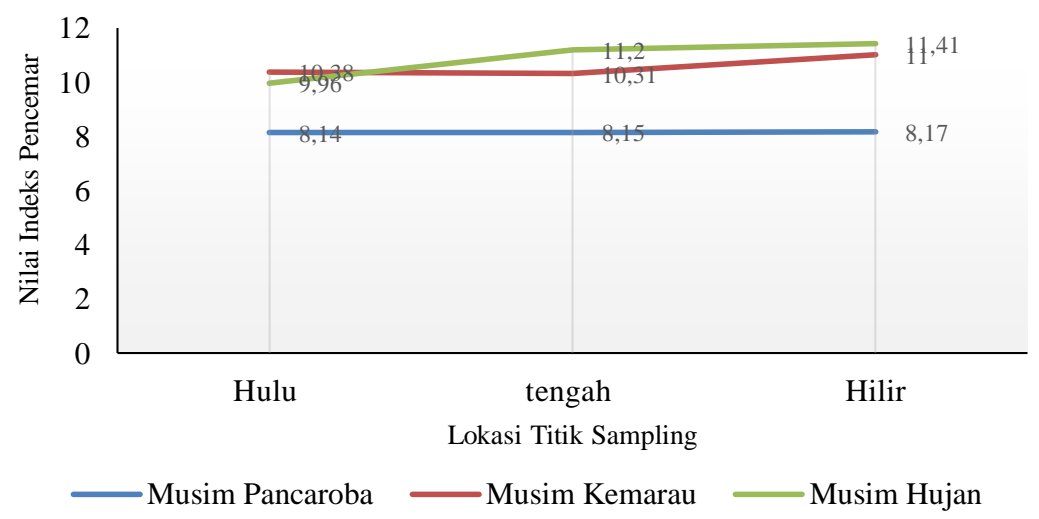

Gambar 3. Nilai Indeks Pencemar Sungai Cibabat Sumber: Hasil perhitungan, 2020

Tabel 4. Rekapitulasi hasil status mutu air Sungai Cibabat

\begin{tabular}{cccc}
\hline \multirow{2}{*}{ Lokasi Sampling } & \multicolumn{3}{c}{ Musim } \\
\cline { 2 - 4 } & Pancaroba & Kemarau & Hujan \\
\hline Hulu & Cemar Sedang & Cemar Berat & Cemar Sedang \\
Tengah & Cemar Sedang & Cemar Berat & Cemar Berat \\
Hilir & Cemar Sedang & Cemar Berat & Cemar Berat \\
\hline
\end{tabular}

Sumber: Hasil perhitungan, 2020

BPM merupakan perkalian antara konsentrasi (baku mutu) suatu parameter dengan debit terukur, sebagai contoh besarnya nilai BPM untuk Parameter BOD yang dihasilkan didapatkan sebesar 20,74 kg/hari. Hal ini diartikan jika suatu zat pencemar masuk ke dalam Sungai Cibabat bernilai kurang dari $\leqslant 20,74 \mathrm{~kg} / \mathrm{hari}$ maka DAS sungai masih memiliki kapasitas untuk menampung zat pencemar dan mempurifikasi dirinya sendiri, sedangkan apabila nilai suatu zat pencemar masuk kedalam DAS Cibabat melebihi nilai atau $\geqslant 20,74$ $\mathrm{kg} /$ hari maka sungai sudah tidak dapat menampung beban pencemar yg masuk untuk parameter BOD. Hasil perhitungan dan perbandingan beban pencemaran maksimum DAS Cibabat di 3 musim pengukuran dapat dilihat pada Tabel 5, Tabel 6, dan Tabel 7.

BPA adalah beban pencemar yang didapatkan/diterima dari kualitas air DAS Cibabat pada kondisi eksisting di tahun 2019, prinsip perhitungan BPA ini sama seperti perhitungan BPM, namun yang membedakan adalah pada perhitungan BPA menggunakan konsentrasi hasil dari pengukuran dan pemantauan kualitas air. Grafik perbandingan BPM dan BPA setiap parameter di ketiga musim pengukuran dapat dilihat melaui Gambar 4, Gambar 5, dan Gambar 6.
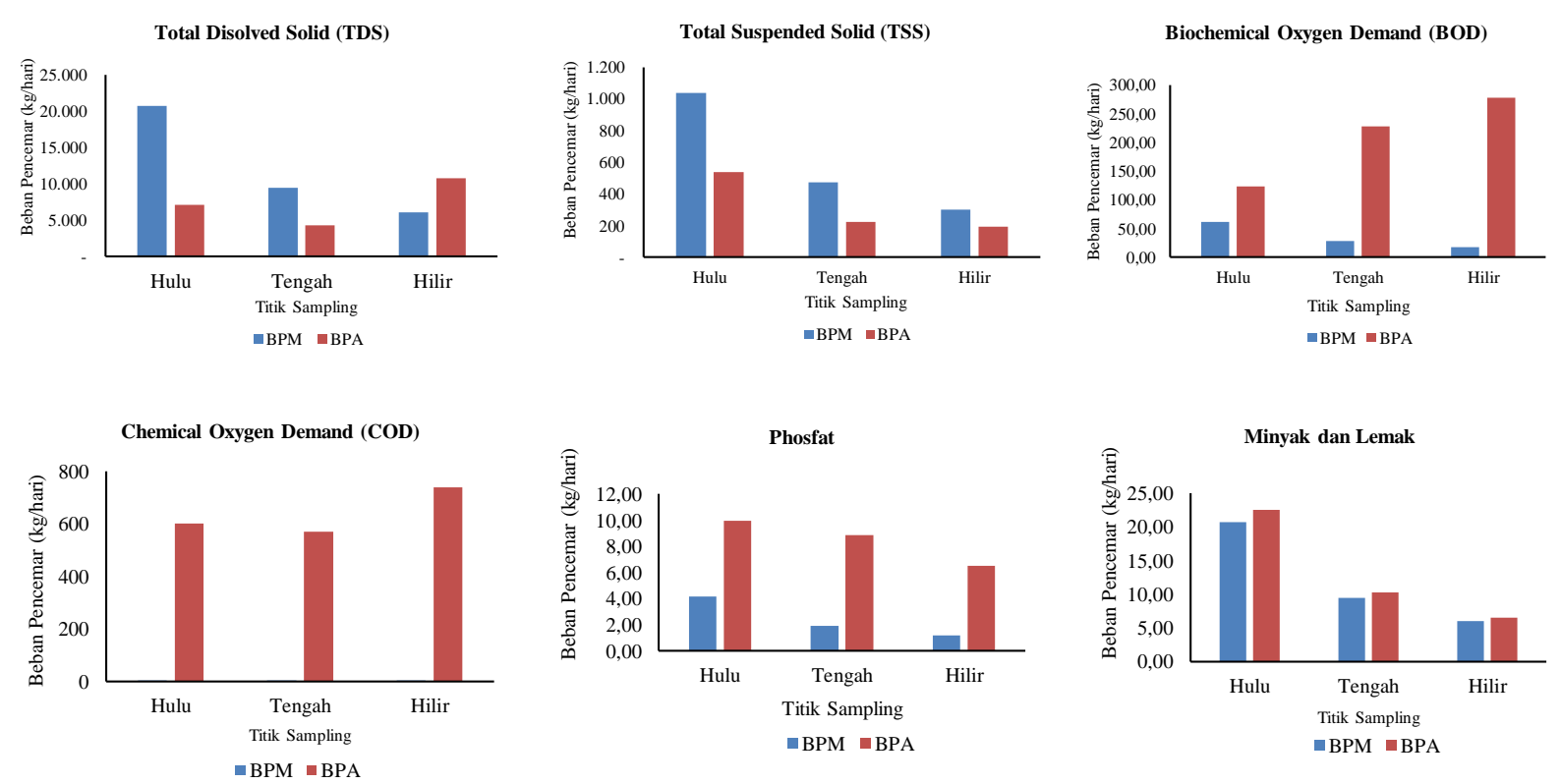

Gambar 4. Perbandingan BPM dan BPA setiap parameter musim pancaroba Sumber: Hasil perhitungan, 2020 
Tabel 5. Perbandingan BPM dan BPA Musim Pancaroba tahun 2019 (kg/hari)

\begin{tabular}{clcccccc}
\hline \multirow{2}{*}{ No } & \multicolumn{2}{c}{ Parameter } & \multicolumn{3}{c}{ BPM } & \multicolumn{3}{c}{ BPA } \\
\cline { 3 - 7 } & & Hulu & Tengah & Hilir & Hulu & Tengah & Hilir \\
\hline 1. & TDS & 20.736 & 9.504 & 6.048 & 7.092 & 4.277 & 10.790 \\
2. & TSS & $1.036,8$ & 475,2 & 302,4 & 539 & 223 & 194 \\
3. & BOD $_{5}$ & 62,2 & 28,5 & 18,1 & 124 & 228,1 & 278,2 \\
4. & COD & 1,2 & 0,6 & 0,4 & 601 & 570,2 & 737,9 \\
5. & Phosphat & 4,2 & 1,9 & 1,2 & 10,0 & 8,8 & 6,5 \\
6. & Minyak dan Lemak & 20,7 & 9,5 & 6,1 & 22,6 & 10,3 & 6,5 \\
\hline
\end{tabular}

Sumber: Hasil Perhitungan, 2020

Keterangan: angka berwarna merah menunjukkan BPA sudah melebihi BPM untuk parameter yang terkait
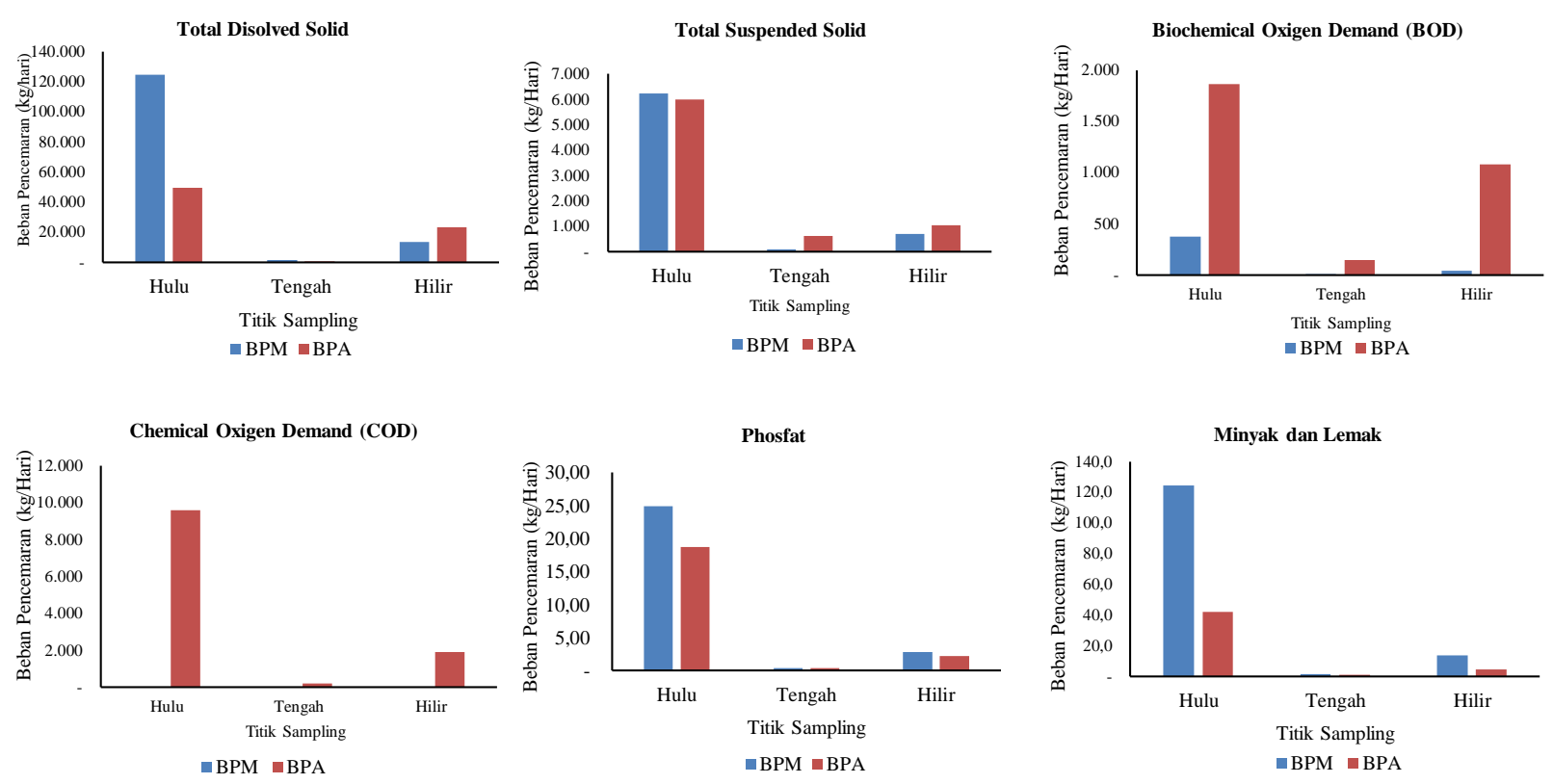

Gambar 5. Perbandingan BPM dan BPA setiap parameter musim kemarau Sumber: Hasil perhitungan, 2020

Tabel 6. Perbandingan BPM dan BPA Musim Kemarau Tahun 2019 (kg/hari)

\begin{tabular}{llcccccc}
\hline \multirow{2}{*}{ No } & \multirow{2}{*}{ Parameter } & \multicolumn{3}{c}{ BPM } & \multicolumn{3}{c}{ BPA } \\
\cline { 3 - 7 } & & Hulu & Tengah & Hilir & Hulu & Tengah & Hilir \\
\hline 1. & TDS & 124.416 & 1.728 & 13.824 & $49.517,6$ & 705,0 & $23.556,1$ \\
2. & TSS & $6.220,8$ & 86,4 & 691,2 & 5972,0 & 597,9 & $1.023,0$ \\
\hline 3. & BOD & 373,3 & 5,2 & 41,5 & $1.866,2$ & 143,4 & $1.078,3$ \\
4. & COD & 7,5 & 0,1 & 0,8 & $9.580,0$ & 193,5 & $1.907,7$ \\
5. & Phosphat & 24,9 & 0,3 & 2,8 & 18,7 & 0,4 & 2,2 \\
6. & Minyak dan Lemak & 124,4 & 1,7 & 13,8 & 42,3 & 1,0 & 4,8 \\
\hline
\end{tabular}

Sumber: Hasil perhitungan, 2020.

Keterangan: angka yang berwarna merah menunjukkan bahwa BPA sudah melebihi BPM untuk parameter yang terkait

Berdasarkan perhitungan BPA dalam ketiga musim, beberapa parameter sudah melebihi BPM yang artinya, kapasitas sungai dalam menampung beban pencemar sudah melewati batas maksimum. Contoh untuk hasil pengukuran parameter $\mathrm{BOD}_{5}$ di bagian hulu hingga hilir Sungai Cibabat pada musim pancaroba sudah tidak dapat menerima beban pencemar lagi. Nilai beban pencemar aktual yang melebihi beban pencemar maksimum menandakan bahwa sungai sudah tercemar. Diperlukannya suatu pengendalian pencemaran sungai dan management sungai yang baik agar sungai tetap memiliki daya dukung lingkungan untuk banyak kebutuhan makhluk hidup lainnya.

Berdasarkan hasil perhitungan beban pencemar yang dihasilkan serta kondisi status mutu air Sungai Cibabat yang dikatakan jauh dari kata baik, menjadikan hal tersebut sebagai dasar dalam menentukan strategi pengendalian pencemaran pada wilayah Sungai Cibabat. 

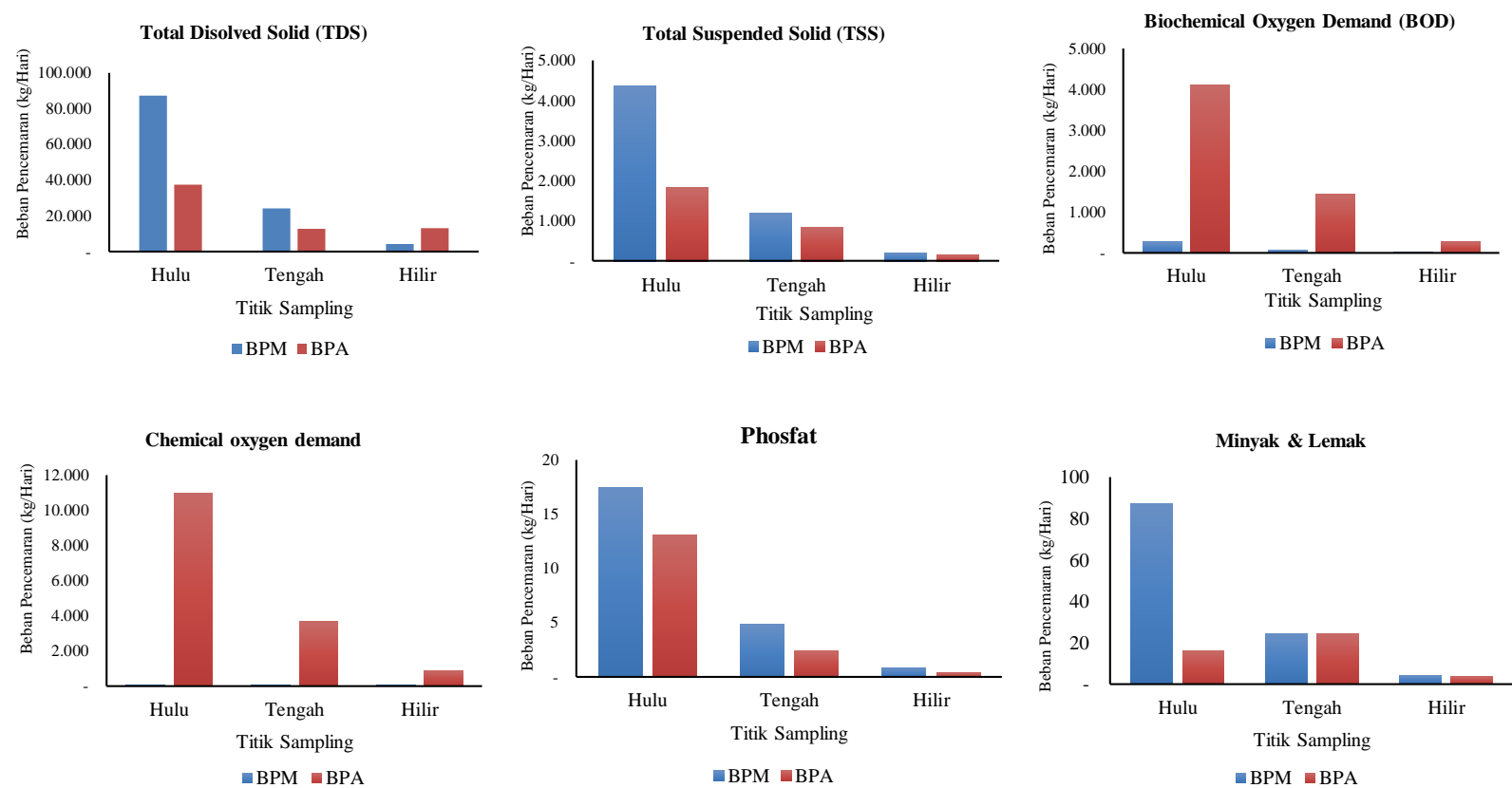

Gambar 6. Perbandingan BPM dan BPA setiap parameter musim hujan Sumber: Hasil perhitungan, 2020.

Tabel 7. Perbandingan BPM dan BPA musim hujan tahun 2019 (kg/hari)

\begin{tabular}{llcccccc}
\hline \multirow{2}{*}{ No } & \multirow{2}{*}{ Parameter } & \multicolumn{3}{c}{ BPM } & \multicolumn{3}{c}{ BPA } \\
\cline { 3 - 8 } & & Hulu & Tengah & Hilir & Hulu & Tengah & Hilir \\
\hline 1. & TDS & 87.264 & 24.192 & 4.320 & $37.523,5$ & $12.821,8$ & $13.288,3$ \\
2. & TSS & $4.363,2$ & $1.209,6$ & 216 & $1.832,5$ & 846,7 & 155,5 \\
3. & BOD & 261,8 & 72,6 & 13,0 & $4.101,4$ & $1.427,3$ & 263,5 \\
4. & COD & 5,2 & 1,5 & 0,3 & $10.995,3$ & $3.653,0$ & 864,0 \\
5. & Phosphat & 17,4 & 4,8 & 0,7 & 13,1 & 2,4 & 0,4 \\
6. & Minyak dan Lemak & 87,3 & 24,2 & 4,3 & 16,2 & 24,2 & 3,7 \\
\hline
\end{tabular}

Sumber: Hasil perhitungan, 2020.

Keterangan: angka yang berwarna merah menunjukkan bahwa BPA sudah melebihi BPM untuk parameter yang terkait

Langkah untuk memperbaiki status mutu air dan beban pencemar sungai agar berada pada kondisi yang baik, pengendalian pencemaran sungai yang dilakukan perlu dimulai dari sektor yang berkontribusi besar. Sebagai sumber memasok polutan terbanyak dari beberapa macam parameter pencemaran air yang tinggi seperti yaitu berasal dari domestik dan industri. Strategi pengendalian yang dapat direkomendasikan untuk sektor domestik maupun industri disesuaikan dengan rencana tata ruang wilayah Kota Cimahi Tahun 2012-2032. Kota Cimahi akan membangun instalasi pengolahan air limbah domestik secara komunal di Kecamatan Cimahi Selatan dan pengolahan limbah rumah tangga dengan sistem offsite dan juga Kota Cimahi menyatakan pembangunan IPAL terpadu untuk industri di Kecamatan Selatan, namun beberapa industri telah memiliki IPAL berskala besar, sehingga strategi untuk mengurangi beban pencemar BOD adalah optimalisasi IPAL pada masing-masing industri [1].

\section{Kesimpulan}

Sungai Cibabat telah tercemar oleh aktivitas penduduk yang berada di DAS, hal tersebut dibuktikan bahwa terdapat 17 parameter yang tercatat pada musim hujan, kemarau, dan pancaroba yang tidak memenuhi baku mutu. Parameter tersebut yaitu TDS, TSS, $\mathrm{BOD}_{5}, \mathrm{COD}$, Phosfat, $\mathrm{Cu}, \mathrm{Pb}, \mathrm{Zn}$, Sulfida, Nitrit, Klorin bebas, Amoniak, Total Coliform, Fecal Coliform, fenol, dan detergen sebagai MBAS. Berdasarkan hasil perhitungan status mutu air di Sungai Cibabat termasuk kategori cemar sedang sampai berat. Kondisi cemar berat terjadi pada musim kemarau dan hujan di bagian tengah dan hilir. Salah satu langkah untuk menanggulangi pencemaran yang terjadi yaitu dengan menentukan beban pencemar yang harus diturunkan di Sungai Cibabat. Hasil perhitungan beban pencemar aktual untuk parameter $\mathrm{BOD}_{5}$ dan COD telah melebihi beban pencemar maksimum di tiga musim pada tiga lokasi titik sampling. 


\section{Daftar Pustaka}

[1] Dinas Lingkungan Hidup Kota Cimahi (2020), Dokumen Informasi Kinerja Lingkungan Hidup (DIKPLH Kota Cimahi, 2020) Buku II Laporan Utama Dokumen Informasi Kinerja Lingkungan Hidup Daerah. Kota Cimahi. Jawa Barat.

[2] Eka Wardhani dan Lina Apriyanti Sulistiowati (2018). Kajian Daya Tampung Sungai Citarik Provinsi Jawa Barat. Jurnal Rekayasa Hijau No.2 | Vol. 2 Juli 2018.

[3] L. A. Sulistiowati, E. Wardhani, "Kajian Dampak Pembuangan Air Limbah Industri PT. X Terhadap Sungai Cikijing di Provinsi Jawa Barat," Rekayasa Hijau: J. Teknologi Ramah Lingkungan, vol. 2(1), 2018.

[4] R. Desriyan, E. Wardhani, "Identifikasi Pencemaran Logam Berat Timbal ( $\mathrm{Pb})$ pada Perairan Sungai Citarum Hulu Segmen Dayeuhkolot sampai Nanjung Lingkungan,” vol. 3(1), 2015.

[5] M. Rachmaningrum, E. Wardhani, K. Pharmawati, "Konsentrasi Logam Berat Kadmium (Cd) pada Perairan Sungai Citarum Hulu Segmen Dayeuhkolot-Nanjung," J. Reka Lingkungan, vol. 3(1), 2015.

[6] A. Arinda, E. Wardhani, "Analisis Profil Konsentrasi Pb di Air Waduk Saguling," Rekayasa Hijau: J. Teknologi Ramah Lingkungan, vol. 2(3), 2018.

[7] E. Wardhani, S. Notodarmojo, D. Roosmini, "Assessment of heavy metal contamination in the water of Saguling Reservoir West Java Province Indonesia," Proceeding E3S Web of Conferences 73, 06009 (2018).

[8] E. Wardhani, S. Notodarmojo, D. Roosmini, "Heavy Metal Speciation in Sediments in Saguling Lake West Java Indonesia," International J. of GEOMATE ISSN: 2186-2990 Japan, vol. 12 Issue 34 pp 146-151, 2017 (a).

[9] E. Wardhani, S. Notodarmojo, D. Roosmini, "Status heavy metal in Sediment of Saguling Lake, West Java. Province," International Journal IOP Conferences Series: Earth and Environmental Science ISSN: 17551315, 17551307 volume 60, 012035, 2017 (b).

[10] E. Wardhani, S. Notodarmojo, D. Roosmini, "Pencemaran Kadmium di Sedimen Waduk Saguling Provinsi Jawa Barat," J. Manusia dan Lingkungan Pusat Studi Lingkungan Hidup, Universitas Gadjah mada (PSLH UGM), vol. 23(3), hal 285-294, 2014.

[11] N. Marlina, W. Brontowiyono, R. Chasna, "Analisis Kualitas Air dan Daya Tampung Sungai dengan Metode Qual2Kw (Studi Kasus: Sungai Code, Yogyakarta)," J. Serambi Engineering, vol. 5 (4), hal 1359-1366, 2020.

[12] R. Christiana, I. M. Anggraini, H. Syahwanti, "Analisis Kualitas Air dan Status Mutu Serta Beban Pencemaran Sungai Mahap di Kabupaten Sekadau Kalimantan Barat," J. Serambi Engineering, vol. 5 (2), hal 941-950, 2020.

[13] Y. Darnas, A. A. Anas, M. A. A. Hasibuan, "Pengendalian Air Lindi Pada Proses Penutupan TPA Gampong Jawa Terhadap Kualitas Air Sumur," J. Serambi Engineering, vol. 5(3), hal: 1165-1176, 2020.

[14] Kementerian Lingkungan Hidup Republik Indonesia, Keputusan Menteri Negara lingkungan Hidup Nomor 115 Tahun 2003 tentang Pedoman Penentuan Status Mutu Air, Jakarta, Indonesia, 2003.

[15] Peraturan Pemerintah Nomor 82 Tahun 2001 tentang Pengelolaan Kualitas Air dan Pengendalian Pencemaran Air.

[16] Metcalf, I. Eddy, Wastewater engineering: Treatment, disposal and reuse: McGraw-Hill New York, USA, 1991. 